Water depth variation

\section{Paleodepth variations on the Eratosthenes Seamount (Eastern Mediterranean): sea-level changes or subsidence?}

\section{S. Spezzaferri ${ }^{1}$ and F. Tamburini ${ }^{2}$}

${ }^{1}$ Department of Geosciences, University of Fribourg, Ch du Musée 7, 1700, Fribourg, Switzerland

${ }^{2}$ Institute of Geology, ETH-Zurich, Universitaetstrasse 16, 8092 Zurich, Switzerland

Received: 21 August 2007 - Accepted: 6 September 2007 - Published: 7 September 2007

Correspondence to: S. Spezzaferri (silvia-spezzaferri@unifr.ch) on the Eratosthens

S. Spezzaferri et al.

2, 115-132, 2007
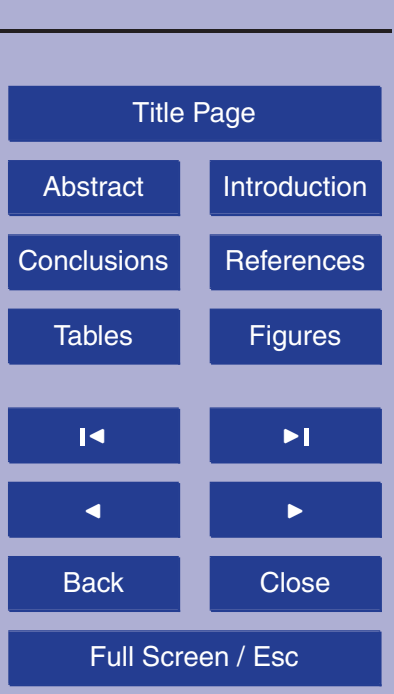

Printer-friendly Version

Interactive Discussion 


\section{Abstract}

The Eratosthenes Seamount (Eastern Mediterranean) is interpreted as a crustal block in process of break up in response to subduction and incipient collision of the African and Eurasian Plates. Subsidence is considered to be the mechanism triggering the

5 Messinian to Pleistocene water deepening above this unique structure. However, the application of a recently developed transfer equation of depth range distribution of benthic foraminifera indicates that sea-level changes may also have played a role, although it was generally minor. In particular, we suggest that across the Miocene/Pliocene boundary and during the Pliocene-Pleistocene, the eustatic signal is frequently coupled with uplifts and subsidence. The uplift of Cyprus across the Pliocene-Pleistocene transition is clearly recorded in the paleodepth curve. Micropaleontological studies and the use of this transfer equation based on the distribution of benthic foraminifera proves to be useful when studying the paleodepth history of complex sites, where tectonic and eustatic signals combine. We also show that marginal seas record global sea-level changes that can be identified even in tectonically active settings.

\section{Introduction}

The Eratosthenes Seamount, located in the Eastern Mediterranean Sea (Fig. 1), is interpreted as a crustal continental block in the process of break up in response to subduction and incipient collision of the African and Eurasian Plates. It represents an important early collisional stage in the general process of plate suturing and mountain building, which is generally not well preserved in the fossil record and has no modern analogue (Robertson et al., 1996; Whiting, 1998).

A transect of four ODP Sites (Site 965 to 968) was drilled on the Eratosthenes Seamount during ODP Leg 160. Data from these locations allowed a better interpretation of the sedimentary and tectonic history of the seamount from the Mesozoic to the present-day. Results demonstrated that this structure was emerged during the

\section{2, 115-132, 2007}

Water depth variation on the Eratosthens

S. Spezzaferri et al.

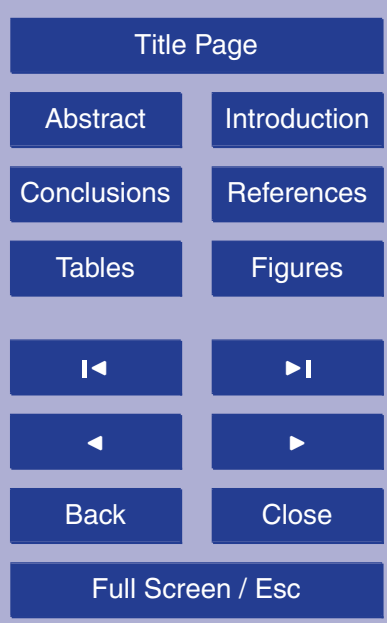

Printer-friendly Version

Interactive Discussion 
"Messinian Salinity Crisis", and rapidly subsided and broke up from the late Miocene to the early Pliocene as result of collision with the Cyprus active margin at the north. Initial impingement took place at about $5 \mathrm{Ma}$ and was followed by intense uplift of Cyprus at about $2 \mathrm{Ma}$ (Robertson et al. 1996; Robertson, 1998a). Seismic evidence also sug5 gests that the Eratosthenes Plateau is presently tectonically active (Robertson et al., 1996).

A preliminary study of the benthic fauna recovered at ODP Hole 967A, drilled at the base of the Northern slope of the seamount, revealed drastic changes in the water depth. However, due to its geologic history, it is currently accepted that the evolution of 10 this structure is related to tectonic changes and that eustatic sea-level variations played a secondary or no role with respect to tectonic-related subsidence in the water deepening above the seamount (e.g., Robertson et al. 1996; Whiting, 1998). Substantial differences in the trend of the sea-level curve of Haq et al. (1988) and the subsidence curves from the Cretaceous to the Pleistocene presented in Whiting (1998) also cor15 roborate this assumption.

The aim of this study is to test whether tectonics, subsidence, or eustasy, or a combination of them triggered the water depth variations above the seamount. We apply the method recently developed by Hohenegger (2005) based on the geometric mean of depth ranges of benthic foraminifera to evaluate variation in paleodepths. The Eratosthenes Seamount has been chosen because it represents an ideal setting where we can test the use of this transfer function in comparison with oxygen stable isotope data. Here, in fact, tectonic-related subsidence may have combined with global sea level changes.

\section{ODP Site 967A}

25 ODP Hole 967A was drilled on a small ridge near the base of the lower northern slope of the seamount (3404.098' $\mathrm{N} ; 32^{\circ} 43.523^{\prime} \mathrm{E}$ ) in a water depth of $2553 \mathrm{mbsl}$ (Fig. 1). Sixteen cores were retrieved with a total core recovery of $95.8 \%$. The recovered Pliocene-

Water depth variation on the Eratosthens

S. Spezzaferri et al.

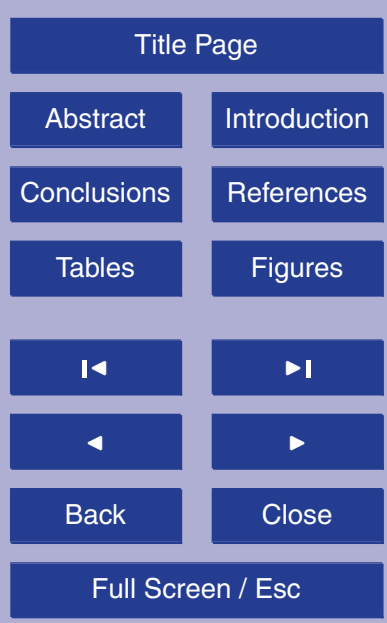

Printer-friendly Version

Interactive Discussion 
Pleistocene sapropel-bearing sequence is approximately $100 \mathrm{~m}$ thick. An about $2 \mathrm{~m}$ thick sequence of calcareous clay underlying these sediments contains abundant ostracods and shallow water benthic foraminifera from the Messinian "Lago-Mare" facies (Emeis et al., 1996; Spezzaferri et al., 1998). The recovered Messinian-Pleistocene 5 sedimentary sequence is almost complete at this hole (Spezzaferri et al., 1998). The only exception is an about 49 ka long hiatus coincident with the Pliocene-Pleistocene transition (Emeis et al., 1996).

\section{Materials and methods}

The detailed biostratigraphy of ODP Hole $967 \mathrm{~A}$ is retained as reported in Emeis et 10 al. (1996) and Spezzaferri et al. (1998). Seventy-nine samples were qualitatively investigated for their benthic foraminiferal content. Three samples per section were taken across the Miocene/Pliocene boundary and 1 to 2 samples per section in the remaining Pliocene to Pleistocene section. The transfer equation developed in Hohenegger (2005) and tested in Spezzaferri et al. (2004) was applied to the depth range distribu15 tion of benthic foraminifera to estimate the paleodepth for each sample:

$x=\left\{\sum_{j=1}^{k}\left[\left(x_{j, \min } x_{j, \max }\right)^{1 / 2}\left(x_{j, \min }-x_{j, \max }\right)\right]\right\} /\left\{\sum_{j=1}^{k}\left[1 /\left(x_{j, \min }-x_{j, \max }\right)\right]\right\}$

Where: $\mathrm{x}=$ paleodepth, $\mathrm{x}_{j, \min }=$ shallower depth range for each benthic species, $\mathrm{x}_{j, \max }$ $=$ deeper depth range for each benthic species, $\mathrm{k}=$ number of species. Depth ranges of the species identified in ODP Hole 967A are from the literature (e.g. Jones, 1994; Sgarrella and Moncharmont-Zei, 1993; Spezzaferri et al. 2004; Hohenegger, 2005).

In particular, the depth ranges used in Hohenegger (2005) were revised according to new data published in specialised monographs on benthic foraminiferal distribution in the Mediterranean Sea that allowed to extend the lower and upper limits of some species (Meric et al., 2004; Rasmussen et al., 2005).
2, 115-132, 2007

\section{Water depth variation} on the Eratosthens

S. Spezzaferri et al.

\section{Title Page}

Abstract Introduction

Conclusions

References

Tables

Figures

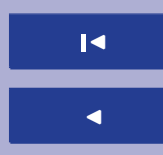

$\Delta \mathbf{I}$

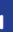

Back

Close

Full Screen / Esc

Printer-friendly Version

Interactive Discussion 
Since post-mortem mixing of species caused by transport, reworking and sediment mixing may bias the paleodepth estimation, the elimination of some species living in water depth not consistent with the assemblage was necessary to reduce the influence of non-overlapping paleodepth signals (Hohenegger, 2005).

5 The paleodepth confidence limit in each sample was also calculated (Fig. 2a). Especially in the Pleistocene part of the sequence, the broad range of the confidence limit is due to the recovery of a lower number of different species compared to other intervals. In this case, the broad range is an effect of the approach used by the paleodepth transfer function, which takes into consideration only the presence of the species and 10 not the all the environmental parameters (e.g. temperature, nature of the substrate, etc.) which control the species depth distribution. However, paleodepth estimation calculated with this method is reliable, as it depends on a geometric mean of gradient values. This is clearly shown by the minimal difference between the real depth of the Site $967(2553 \mathrm{~m})$ and the estimated depth of the upper part of the studied sequence 15 (2549.5 m).

The paleodepth curve is plotted against the age model obtained using the astronomically calibrated ages of bioevents as in Emeis et al. (1996). Depth ranges for each species are shown in Table 1. The complete range chart showing the distribution of benthic foraminifera in the sediments from the Eratosthenes Seamount and their depth

\section{Results}

The paleodepth curve obtained for the Eratosthenes Seamount (Fig. 2b) shows three major drastic variations. (1) Very low paleodepth values (less than $20 \mathrm{~m}$ ) are observed in the Messinian part of the sedimentary sequence. (2) Values further increase rapidly 25 in the early Pliocene (about 5.1 Ma). The paleodepth curve shows only minor fluctuations throughout most of the Pliocene with values from about $200 \mathrm{~m}$ and never exceeding $712 \mathrm{~m}$. (3) In the Pleistocene a strong deepening from $456 \mathrm{~m}$ to 1060 is observed 
between 1.7 and 1.5 Ma. The deepening trend continues upward with values reaching the present depth of about $2549.5 \mathrm{~m}$.

\section{Discussion}

\subsection{Sea-level changes in the Mediterraean Sea}

5 The paleogeography and paleoceanography of the Mediterranean sea experienced drastic changes during the latest Miocene (uppermost part of the Messinian stage), when it became temporarily isolated from the Atlantic Ocean as result of the interaction of plate motion and glacio-eustatic sea-level changes (e.g. Spezzaferri et al., 1998; McKenzie et al., 1999). This isolation resulted in a "salinity crisis" of the Mediterranean, 10 whereby the world ocean lost $6 \%$ of its salinity and about one million cubic kilometres of evaporites were deposited on the floor of the deep Mediterranean Basin (e.g., Hsu et al., 1973; Ryan, 1973). After the re-establishment of open marine conditions in the earliest Pliocene at 5.332 Ma (van der Laan, 2006), the Mediterranean Basin reached its actual configuration through additional eustatic changes and local tectonic processes, 15 which influenced the geological setting and the sedimentation during the Pliocene and Pleistocene (Robertson, 1998a).

McKenzie et al. (1999) demonstrated that a global sea level rise at $5.33 \mathrm{Ma}$ ended the "salinity crisis" in the Mediterranean and forced the backstepping of the carbonate platforms in the Bahamas, implying a strong eustatic influence at least in this time. 20 The initial flood was followed by the establishment of a shallow connection to the Atlantic (initial formation of the Strait of Gibraltar) becoming efficient coincident with the Zone MPI1/MPI2 boundary in the lower Pliocene. Recent studies have linked the basal Pliocene flooding to a tectonic event rather than a global eustatic sea level rise (e.g., Duggen et al, 2005; Van der Laan et al., 2006).

25 To identify possible relationships between paleodepth variation on the Eratosthenes Seamount, sea level changes and/or tectonic events, the paleodepth curve was com-
$2,115-132,2007$

Water depth variation on the Eratosthens

S. Spezzaferri et al.

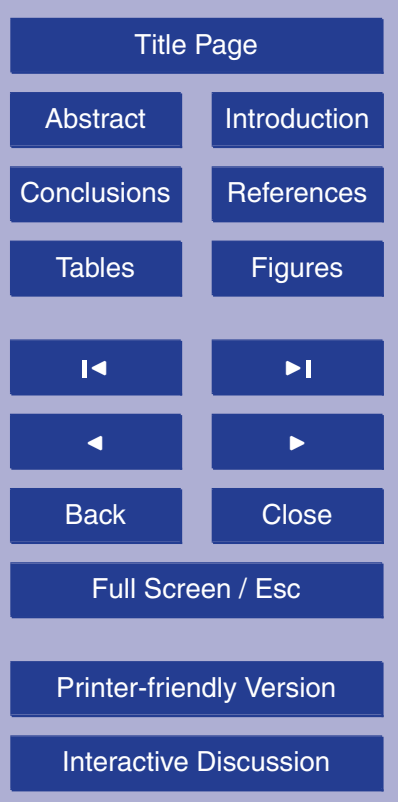


pared with the stack of benthic $\delta^{18} \mathrm{O}$ records (Fig. 2c) from 57 globally distributed sites, but mostly in the Atlantic Ocean, aligned by an automated graphic correlation algorithm (Lisieki and Raymo, 2005). The relationship between the composite oxygen isotope record and the eustatic episodes consistent with the geological record of ice-sheets 5 evolution was previously demonstrated by Abreu and Haddad (1998) and Abreu and Anderson (1999), among others. In particular, negative excursions of the $\delta^{18} \mathrm{O}$ values should correspond to high sea-level stands and positive excursions to low sea-level stands.

\subsubsection{Overall trends}

10 Comparison between the paleodepth curve and the composite isotope record shows an opposite trend of the two curves throughout the investigated interval. The composite isotope record shows the well-known cooling trend from $5.5 \mathrm{Ma}$ to present, indicating also a trend towards overall lower sea level. On the other hand, the paleodepth curve observed at the Eratosthenes Seamount indicates deepening in the seawater 15 (Figs. 2b-c). Since several lines of evidence confirm that rapid subsidence took place on the Eratosthenes Seamount from the early Pliocene, the tectonic history of the area accounts for the discrepancy observed between the sea level and the paleodepth curves.

However, the comparison of these records in selected time slices (latest Messinianlowermost Pliocene; remaining part of the Pliocene, Pleistocene) shows that single excursions in the curves can be correlated indicating a causal link between paleodepths and sea level changes.

\subsubsection{Upper Messinian to lower Pliocene (5.5 to 4.0 Ma)}

The resolution during the latest Messinian (before $5.33 \mathrm{Ma}$ ) is poor, however, this in25 terval seems to coincide with a negative excursion in the stack of $\delta^{18} \mathrm{O}$ isotope curve and with the initiation of the deepening trend in the paleodepth curve (Fig. 3a). This
2, 115-132, 2007

Water depth variation on the Eratosthens

S. Spezzaferri et al.

\section{Title Page}

Abstract Introduction

Conclusions References

Tables

Figures

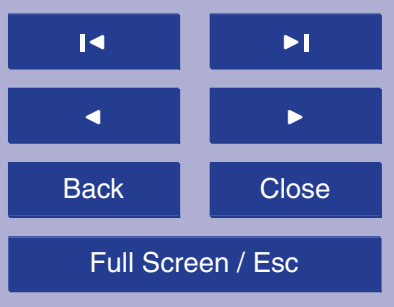

Printer-friendly Version

Interactive Discussion 
correspondence indicates that a transgressive event may have taken place just before the Miocene/Pliocene as suggested by McKenzie et al. (1999). Duggen et al. (2003) suggested that westward migrating late Miocene uplift might have induced slumping from the Gibraltar arc into the Atlantic abyssal plain which, coupled with faulting, 5 may have allowed a new marine gateway to open at the Strait of Gibraltar. More recently Van der Laan et al. (2006) observed that at the Louljia-A section in Tunisia the Miocene/Pliocene boundary is characterized by a decrease in the benthic $\delta^{18} \mathrm{O}$ correlated to an obliquity-controlled cycle between TG7 and TG5 and not to TG5 itself, as suggested by Shackleton et al. (1995) and McKenzie et al. (1999). Between 5.332 and $10 \quad 5.2 \mathrm{Ma}$ the stack of $\delta^{18} \mathrm{O}$ isotope curve and the paleodepth curve show opposite trends supporting the hypothesis of a stronger influence of the tectonic signal with only minor influence of eustasy.

Correspondence between the two curves with enhanced deepening from $170 \mathrm{~m}$ to over $300 \mathrm{~m}$ is observed between 5.2 and $5.1 \mathrm{Ma}$. This interval coincides with the 15 re-establishment of efficient connection between the Atlantic and the Mediterranean (Spezzaferri et al., 1998).

The overall trends of the two curves do not coincide up to $4.0 \mathrm{Ma}$. This may reflect the rapid break-up and subsidence produced by the incipient collision and extensional faulting of the seamount (Robertson, 1996; Robertson, 1998b) coupled with a slight influence of sea-level changes.

\subsubsection{Middle to late Pliocene (4.0 to $2.5 \mathrm{Ma})$}

The paleodepth curve shows small variations in amplitude throughout this interval. The composite oxygen isotope curve displays larger fluctuations but the overall trend is similar to that of paleodepth (Fig. 3b). A few positive and negative excursions can be compared in the two curves.

The continued erosion of the Gibraltar Soil resulted in the stabilisation of efficient connections between the Atlantic Ocean and the Mediterranean Sea after 5.1 Ma. A complete reorganisation and stabilisation of the circulation patterns took place in the

Water depth variation on the Eratosthens

S. Spezzaferri et al.

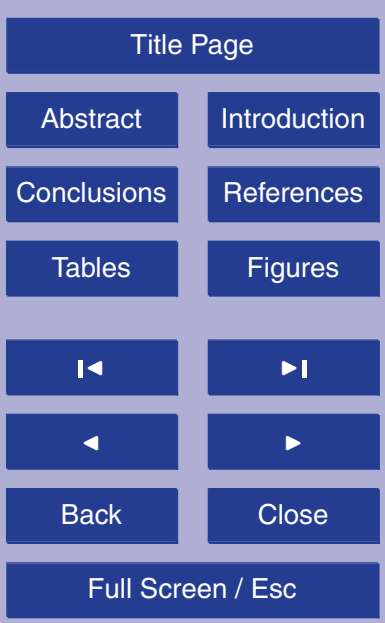

Printer-friendly Version

Interactive Discussion 
Atlantic Ocean after the final closure of the Isthmus of Panama at approximately $4.6 \mathrm{Ma}$ (e.g., Haug and Tiedemann, 1998; Kron et al., 2000).

Efficient connections and the new and more stable current system may have resulted in a relatively strong influence of sea-level changes in the Mediterranean Basin from

$54.52 \mathrm{Ma}$ to $1.75 \mathrm{Ma}$. The similar overall trend of the paleodepth and composite oxygen isotope curve and the lacking of abrupt depth changes may also reflect a reduced tectonic activity during this interval.

\subsubsection{Pleistocene to Holocene (2.5 Ma to present)}

The Pliocene-Pleistocene transition experienced renewed tectonic disturbance and intensified subsidence leading to tectonic collapse of the seamount. Robertson et al. (1998) related the 4.9 ka hiatus to the deformation of the Eratosthenes plateau area, probably produced by block faulting of the underlying pre-Pliocene-Pleistocene rocks. These authors suggested synchronicity between the Eratosthenes collapse and the main uplift of Cyprus, which took place after the late Pliocene. Indeed, the paleodepth 15 curve shows a deepening of about $2110 \mathrm{~m}$ at $1.5 \mathrm{Ma}$ (Fig. 3c) indicating that this variation may be related to a major tectonic event such as the collapse of the structure triggered by the uplift of Cyprus rather than a sea level change. In the Pleistocene a coupled influence of sea-level changes superimposed to tectonic collapse of the structure can be observed. The oxygen isotope record of Kroon et al. (1998) obtained for ODP Hole 967A from approximately 0.26 and $3.99 \mathrm{Ma}$ also shows an upward trend toward more positive values confirming, at least in this interval, a partial influence of sea level variation.

\section{Conclusions}

The paleodepth history of the Eratosthenes Seamount as revealed by the use of the 25 transfer function and by the comparison with global benthic $\delta^{18} \mathrm{O}$, is mainly dominated

Water depth variation on the Eratosthens

S. Spezzaferri et al.

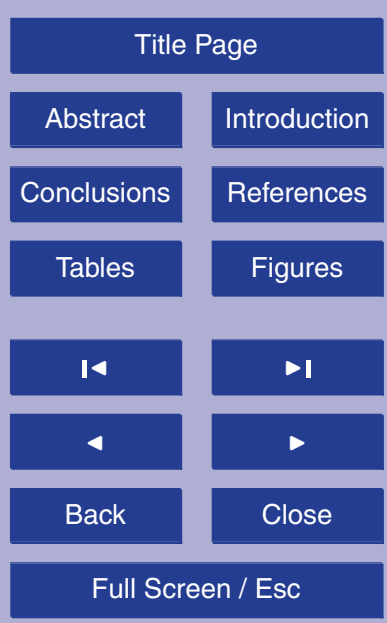

Printer-friendly Version

Interactive Discussion 
by the tectonic events and subsidence of the seamount linked to the uplift of Cyprus. However, it is clear that minor shifts in the paleodepth of this location are causally linked to global sea level changes that played a role in the deepening of the Seamount from the Miocene/Pliocene boundary to the present. Therefore, this study suggests 5 that marginal seas record global sea-level changes, and they can be identified even in geological settings where tectonic events are dominant.

Acknowledgements. Thanks to the Ocean Drilling Program for inviting SS on board Leg 160 and providing samples for this study. S. Spezzaferri would like to thank the shipboard party for scientific discussion during and after the cruise and to F. Rögl (Vienna) for suggestions about 10 depth ranges of foraminifera. H. Hohenegger (Vienna) is acknowledged for the development of the method for paleodepth estimations.

\section{References}

Abreu, V. S. and Anderson, J. B.: Glacial eustasy during the Cenozoic: Sequence stratigraphic implications, AAPG Bull., 82, 1385-1400, 1998.

15 Abreu, V. S. and Haddad, G. A.: Glacioeustatic fluctuations: the mechanism linking stable isotope events and sequence stratigraphy from the Early Oligocene to Middle Miocene, in: Mesozoic and Cenozoic sequence stratigraphy of European Basins, edited by: de Graciansky, P.-C., Hardenbol, J., Jacquin, T., and Vail, P. R., SEPM Special Publication, 60, 245-259, 1998.

DiStefano, E., Sprovieri, R., and Scarantino, S.: Chronology of biostratigraphic events at the base of the Pliocene, Paleopelagos, 6, 401-414, 1996.

Duggen, S., Hoernle, van den Bogaard, P., Rüpke, L., and Morgan, J. P.: Deep roots of the Messinian salinity crisis, Nature, 422, 602-606, 2005.

Emeis, C.-K., Roberson, A. H. F., Richter, K., et al.: Proceedings of the ODP, Initial Reports, 160, 1996.

Haq, B. U, Hardenbol, J., and Vail, P. R.: Mesozoic and Cenozoic chronostratigraphy and cycles of sea-level change, in: Sea-Level Changes: An Integrated Approach, edited by: Wilgus C. K., Hastings, B. S., Kendall, C. G. St. C., et al., SEPM Special Publication, 42, 71-108, 1988.

Water depth variation on the Eratosthens

S. Spezzaferri et al.

\section{Title Page}

Abstract Introduction

Conclusions References

Tables

Figures

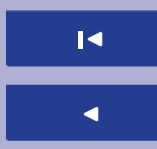

DI

Back

Close

Full Screen / Esc

Printer-friendly Version

Interactive Discussion 
Haug, G. H. and Tiedemann, R.: Effect of the formation of the Isthmus of Panama on Atlantic Ocean thermohaline circulation, Nature, 393, 673-676, 1998.

Hohenegger, J.: Simple estimation of paleogradients based on presence/absence data: exemplified for paleodepth using benthic foraminifera, Palaeogeogr., Palaeoclimatol. Palaeoecol., 217, 2005.

Hsu, K. J., Cita, M. B., and Ryan, W. B. F.: The origin of the Mediterranean evaporites, in: Proc. ODP, Init. Reports edited by: Ryan, W. B. F., Hsu, K. J., Cita, M. B., et al., 13 (Pt. 2), 1203-1231, 1973.

Jones, R. W.: The Challenger Foraminifera, The Natural History Museum, Oxford University Press, London, 1994.

Kroon, D., Alexander, I., Little, M., Lourens, L. J., Matthewson, A., Robertson, A. H. F., and Sakamoto, T.: Oxygen isotope and sapropel stratigraphy in the Eastern Mediterranean during the last 3.2 million years, in: Proc. ODP, Sci. Results, edited by: Robertson, A. H. F., Emeis, K.-C., Richter, C., and Camerlenghi, A., 160, 181-189, 1998.

15 Kroon, D., Williams, T., Pirmez, C., Spezzaferri, S., Sato, T., and Wright, J. D.: Coupled early Pliocene-middle Miocene bio-cyclostratigraphy of Site 1006 reveals orbitally induced patterns of Great Bahama Bank carbonate production, in: Proc. ODP, Sci. Results, edited by: Eberli, G. P., Swart, P. K., Malone, M. J., 166, 155-166, 2000.

Lisieki, L. E. and Raymo M. E.: A Pliocene-Pleistocene stack of 57 globally distributed benthic D 18 O records, Paleoceanography, 20, PA1003, doi:10.1029/2004PA001071, 2005.

McKenzie, J. A., Spezzaferri, S., and Isern, A.: The Miocene/Pliocene boundary in the Mediterranean and Bahamas: implications for a global flooding event in the earliest Pliocene, Mem. Soc. Geol. It., 54, 93-108, 1999.

Meric, E., Avsar, N., and Bergin, F.: Benthic foraminifera of Eastern Aegean Sea (Turkey) systematic and ecology, Turk. Marine Res. Found., 18, 2004.

Rasmussen T. L., Hastrup, A., and Thomsen, E.: Lagoon to deep-water foraminifera and ostracods from the Plio-Pleistocene Kallithea Bay Section, Rhodes, Greece. Cushman Found. Spec. Publ., 39, 2005.

Ryan, W. B. F. and Hsu, K. J.: Proceedings of the ODP, Initial Reports, v. 13 (Pt. 2), 1973.

30 Robertson, A. H. F. and the Shipboard Scientific Party: Role of the Eratosthenes Seamount in collisional processes in the Eastern Mediterranean, in: Proc. ODP, Init. Reports, edited by; Emeis, C.-K., Roberson, A. H. F., Richter, K., et al., 160, 513-520, 1996.

Robertson, A. H. F.: Late Miocene paleoenvironments and tectonic setting of the southern

Water depth variation on the Eratosthens

S. Spezzaferri et al.

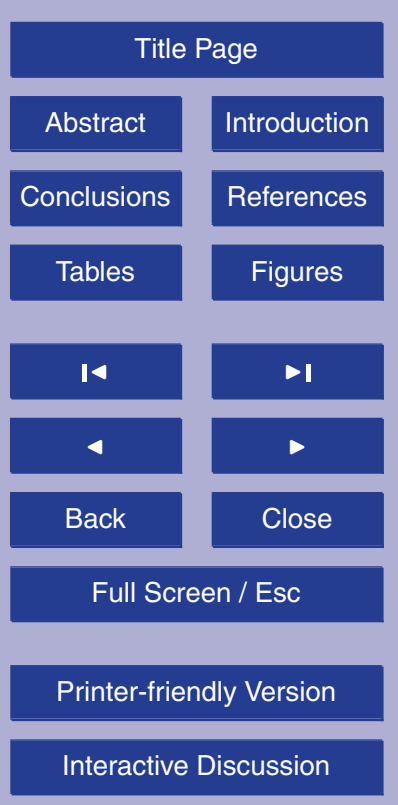


margin of Cyprus and the Eartosthenes Seamount, in: Proc. ODP, Sci. Results, edited by: Emeis, K. C., Robertson A. H. F., Richter, C., and Camerlenghi, A., 160, 453-463, 1998 a.

Robertson, A. H. F.: Significance of Lower Pliocene mass-flow deposits for the timing and process of collision of the Eratosthenes Seamount with the Cyprus active margin, in: Proc. ODP, Sci. Results, edited by: Emeis, K. C., Robertson A. H. F., Richter, C., and Camerlenghi, A., 160, 465-481, 1998b.

Robertson, A. H. F., Emeis, K.-C., Richter, C., Blanc-Valleron, K.-C., Bouloubassi, I., Brumsack, H. J., Cramp, A., Di Stefano, E., Flecker, R., Frankel, E., Howell, M. W., Janecek, T.R., Jurado-Rodriguez, M.-J., Kemp, A. E. S., Koizumi, I., Kopf, A. , Major, C. O., Mart, Y., Pribnow, D. F. C., Rabaute, A., Roberts, A. P., Rullkotter, J. H., Sakamoto, T., Spezzaferri, S., Staerker, T. S., Stoner, J. S., Whiting, B. M., and Woodside, J. M.: Collision-related break-up of a carbonate platform (Eratosthenes "Seamount") and mud volcanism on the Mediterranean Ridge: preliminary synthesis and implications of tectonic results of ODP Leg 160 in the Eastern Mediterranean Sea., Geol. Soc. London, 243-271, 1998.

15 Sgarrella, F. and Moncharmont-Zei, M.: Benthic foraminifera in the Gulf of Naples (Italy): systematic and autoecology, Boll. Soc. Paleontol. It., 32, 145-264, 1993.

Shackleton, N. J., Crowhurst, S. J., Hagelberg, T. K., Pisias, N. G., and Schneider, D. A.: A new late Neogene time scale: application to Leg 138 sites, in: Proc. ODP, Sci. Results, edited by: Mayer, L., Pisias, N., Janecek, T., et al., 138, 73-101, 1995.

Spezzaferri, S., Cita, M. B., and McKenzie, J. A.: The Miocene/Pliocene boundary in the eastern Mediterranean: Results from Leg 160, Sites 967 and 969, in: Proc. ODP, Sci. Results edited by: Emeis, K. C., Robertson, A. H. F., Richter, C., and Camerlenghi, A., 160, 9-28, 1998.

Spezzaferri, S., Rögl, F., Coric, S., and Hohenegger, J.: Paleoenvironmental reconstruction and agglutinated foraminifera form the Karpatian/Badenian(Early/Middle Miocene) transition in the Styrian Basin (Austria, Central Paratethys), in: International Workshop on Agglutinated Foraminifera, Grzybowski Foundation, edited by: Bubik, M. and Kaminski, M. A., Sixth, Special Publication, 423-459, 2004.

Sprovieri, R., DiStefano, E., Howell, M., Sakamoto, T., Di Stefano, A., and Marino, M.: Integrated calcareous plankton biostratigraphy and cyclostratigraphy at Site 964, in: Proc. ODP, Sci. Results, edited by: Emeis, K. C., Robertson, A. H. F., Richter, C., and Camerlenghi, A., 160, 155-180, 1998.

Van der Laan, E., Snel, E., de Kaenel, E., Hilgen, F. J., and Krijgsman, W.: No major deglacia-
2, 115-132, 2007

Water depth variation on the Eratosthens

S. Spezzaferri et al.

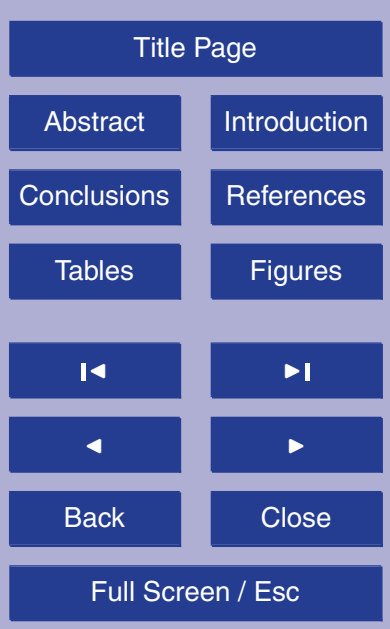

Printer-friendly Version

Interactive Discussion 
tion across the Miocene-Pliocene boundary: Integrated stratigraphy and astronomical tuning of the Loulja sections (Bou Regreg area, NW Morocco), Paleoceanography, 21, PA3011, doi:10.1029/2005PA001193, 2006.

Whiting, B. M.: Subsudence record of early-stage continental collision, Eratosthenes platform (Sites 966 and 967), in: Proc. ODP, Sci. Results, edited by: Emeis, K. C., Robertson, A. H. F., Richter, C., and Camerlenghi, A., 160, 509-515, 1998.
2, 115-132, 2007

\section{Water depth variation} on the Eratosthens

S. Spezzaferri et al.

\begin{tabular}{|c|c|}
\hline \multicolumn{2}{|c|}{ Title Page } \\
\hline Abstract & Introduction \\
\hline Conclusions & References \\
\hline Tables & Figures \\
\hline I4 & \multicolumn{1}{|c|}{} \\
\hline 4 & \multicolumn{1}{c|}{ Close } \\
\hline Back & \\
\hline Full Screen / Esc \\
\hline Printer-friendly Version
\end{tabular}


Table 1. List of benthic foraminifera identified at Hole 967A and their depth range.

\begin{tabular}{|c|c|c|c|c|c|}
\hline Species & Minimum & Maximum & Species & Minimum & Maximum \\
\hline & Depth (mbsl) & Depth (mbsl) & & Depth (mbsl) & Depth (mbsl) \\
\hline Ammonia tepida & 2 & 80 & Melonis pompilioides & 50 & 4800 \\
\hline Anomalinoides helicinum & 100 & 1000 & Miliolinella subrotunda & 30 & 4500 \\
\hline Anomalinoides minimum & 515 & 4000 & Nonion commune & 60 & 2000 \\
\hline Articulina tubulosa & 1300 & 5000 & Oolina faveolata & 60 & 300 \\
\hline Astrononion stelligerum & 10 & 550 & Oridorsalis stellatus & 200 & 4000 \\
\hline Bigenerina nodosaria & 60 & 3000 & Oridorsalis umbonatus & 200 & 4000 \\
\hline Bolivina dilatata & 15 & 3000 & Parrelloides bradyi & 450 & 3300 \\
\hline Bolivina punctata & 50 & 2000 & Parrelloides robertsonianus & 450 & 3300 \\
\hline Bolivina subspinescens & 25 & 2960 & Planulina ariminensis & 70 & 1200 \\
\hline Bulimina aculeata & 5 & 4000 & Pleurostomella alternans & 20 & 1000 \\
\hline Chilostomella mediterranensis & 500 & 1500 & Pullenia bulloides & 70 & 4000 \\
\hline Cibicidoides italicus & 100 & 2000 & Pullenia osloensis & 70 & 4000 \\
\hline Cibicidoides ornatus & 20 & 4000 & Pullenia quadriloba & 70 & 4000 \\
\hline Cibicidoides pachyderma & 70 & 4000 & Pullenia quinqueloba & 70 & 4000 \\
\hline Cibicidoides ungerianus & 50 & 4000 & Pyrgo murrhina & 500 & 5000 \\
\hline Cribrobulimina serpens & 100 & 1000 & Quinqueloculina bicarinata & 20 & 3000 \\
\hline Dentalina leguminiformis & 13 & 1000 & Quinqueloculina laevigata & 3 & 200 \\
\hline Eggerella brady & 100 & 4000 & Quinqueloculina viennensis & 3 & 200 \\
\hline Elphidium spp. & 5 & 100 & Sigmoilinita tenuis & 70 & 4000 \\
\hline Fissurina longirostris & 50 & 1700 & Sigmoilopsis schlumbergeri & 50 & 3000 \\
\hline Globocassidulina subglobosa & 50 & 4000 & Siphonina reticulata & 55 & 1500 \\
\hline Gyroidina neosoldanii & 100 & 5000 & Siphonodosaria hispida & 100 & 2500 \\
\hline Gyroidinoides altiformis & 100 & 4000 & Sphaeroidina bulloides & 25 & 4500 \\
\hline Gyroidinoides laevigatus & 100 & 3000 & Stainforthia complanata & 16 & 500 \\
\hline Hyalinea baltica & 60 & 4000 & Stilostomella antillea & 100 & 2500 \\
\hline Karreriella bradyi & 130 & 2000 & Stilostomella monilis & 100 & 2500 \\
\hline Lagena clavata & 30 & 500 & Triloculina tricarinata & 62 & 4300 \\
\hline Lenticulina cultrata & 50 & 4500 & Uviegrian rutila & 500 & 1000 \\
\hline Lenticulina gibba & 50 & 4500 & Uvigerina peregrina & 100 & 1500 \\
\hline Lenticulina inornata & 50 & 3500 & Uvigerina pymaea & 100 & 2500 \\
\hline Lenticulina rotulata & 50 & 3500 & Uvigerina spinosa & 600 & 4000 \\
\hline Lobatula lobatula & 5 & 120 & Uvigerina striata & 100 & 1500 \\
\hline Marginulina sp. & 50 & 4000 & Valvulineria marmorea & 30 & 1000 \\
\hline Martinottiella communis & 100 & 3000 & Vulvulina pennatula & 500 & 1300 \\
\hline Martinottiella perparva & 100 & 3000 & & & \\
\hline
\end{tabular}

2, 115-132, 2007

Water depth variation on the Eratosthens

S. Spezzaferri et al.
Title Page

Abstract Introductio

Conclusions References

Tables Figures

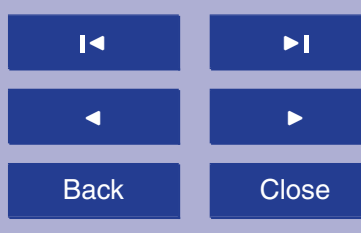

Full Screen / Esc

Printer-friendly Version

Interactive Discussion 
2, 115-132, 2007

Water depth variation on the Eratosthens

S. Spezzaferri et al.

\begin{tabular}{|c|c|}
\hline \multicolumn{2}{|c|}{ Title Page } \\
\hline Abstract & Introduction \\
\hline Conclusions & References \\
\hline Tables & Figures \\
\hline I4 & \\
\hline 4 & $\bullet$ \\
\hline Back & Close \\
\hline Full Screen / Esc
\end{tabular}

Printer-friendly Version

Interactive Discussion 

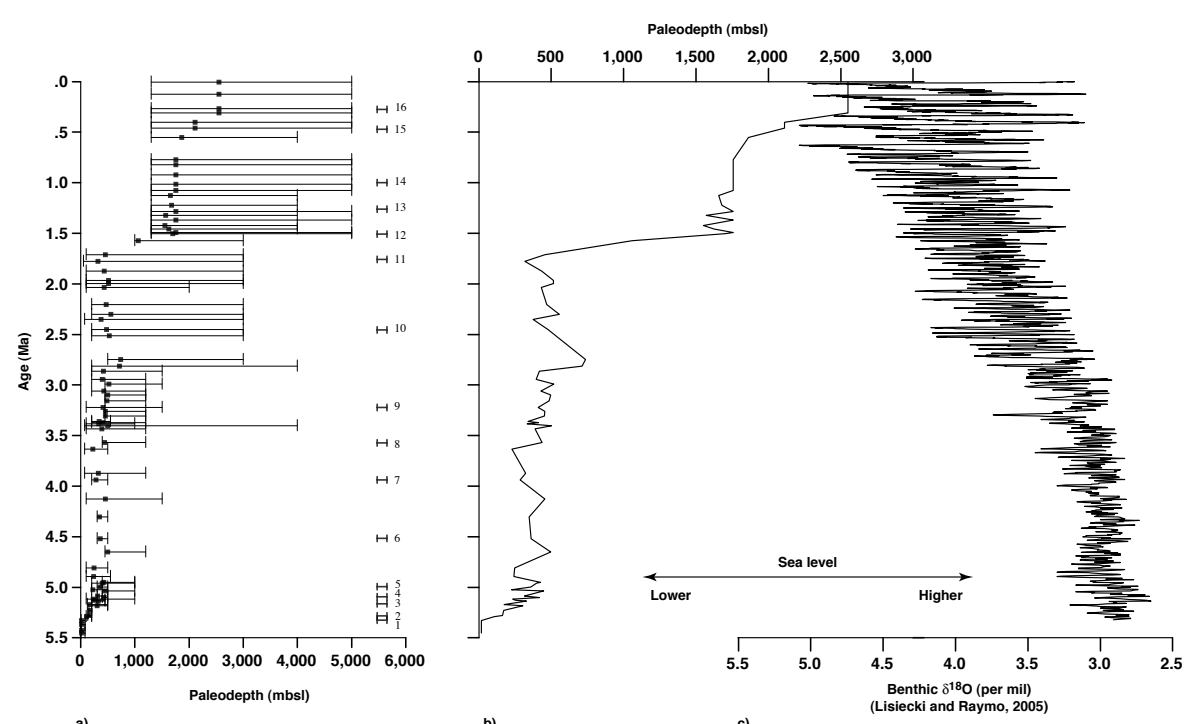

Fig. 2. (a) confidence interval of water depth for each sample, (b) paleodepth curve, (c) stack of benthic $\delta^{18} \mathrm{O}$ records (Lisieki and Raymo, 2005) and the paleodepth curve. Horizontal bars represent the bioevents listed in Figs. $3 \mathrm{a}-\mathrm{c}$.
Water depth variation on the Eratosthens

S. Spezzaferri et al.

\begin{tabular}{|c|c|}
\hline \multicolumn{2}{|c|}{ Title Page } \\
\hline Abstract & Introduction \\
\hline Conclusions & References \\
\hline Tables & Figures \\
\hline I4 & \\
\hline 4 & $\bullet$ \\
\hline Back & Close \\
\hline Full Screen / Esc
\end{tabular}

Printer-friendly Version

Interactive Discussion 


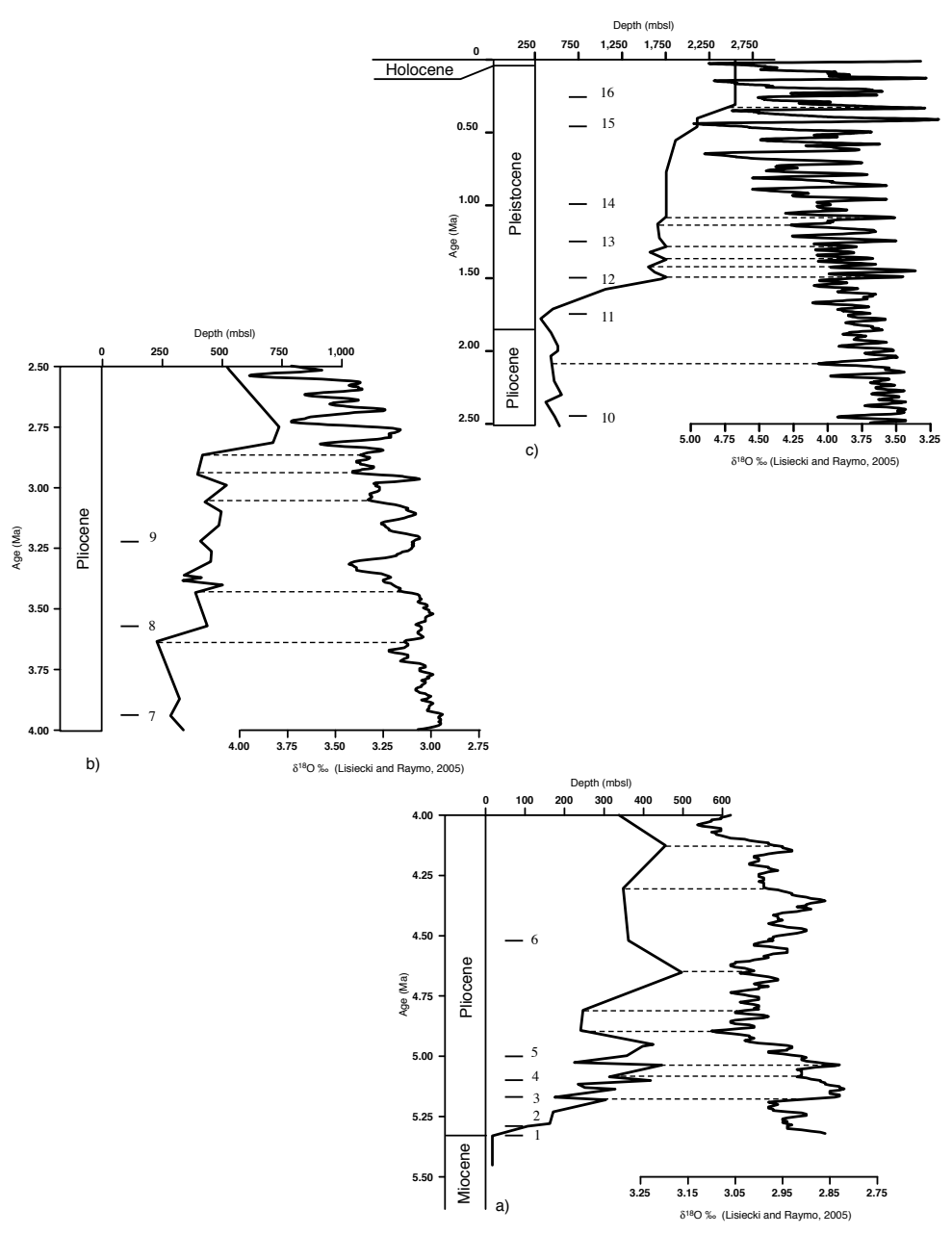

2, 115-132, 2007

Water depth variation on the Eratosthens

S. Spezzaferri et al.

\begin{tabular}{|c|c|}
\hline \multicolumn{2}{|c|}{ Title Page } \\
\hline Abstract & Introduction \\
\hline Conclusions & References \\
\hline Tables & Figures \\
\hline I & \\
\hline 4 & $\triangleright \mathbf{I}$ \\
\hline Back & Close \\
\hline Full Screen / Esc
\end{tabular}

Printer-friendly Version

Interactive Discussion

Fig. 3. 


\section{Water depth variation} on the Eratosthens

\section{S. Spezzaferri et al.}

Fig. 3. (a) Comparison between the stack of benthic $\delta^{18} \mathrm{O}$ records (Lisieki and Raymo, 2005) and paleodepth curves from $5.5 \mathrm{Ma}$ to $4.0 \mathrm{Ma}$. $1=5.332 \mathrm{Ma}$ re-establishment of open marine conditions; $2=5.29 \mathrm{Ma}$ base of Sphaeroidinellopsis acme; $3=$ top of Sphaeroidinellopsis acme; $5.17=$ First Common Occurrence (FCO) of Globorotalia margaritae; $5=5.00 \mathrm{Ma} ; 6=$ 4.52 First Occurrence (FO) of Globorotalia puncticulata. (b) Comparison between the composite oxygen isotope and the paleodepth curves from 4.00 Ma to $2.5 \mathrm{Ma} .7=3.94 \mathrm{Ma}$ Last Common Occurrence of Globorotalia margaritae; $8=3.57 \mathrm{Ma} \mathrm{LO}$ of G. puncticulata; $9=3.22 \mathrm{Ma}$ LO Sphaeroidinellopsis. (c) Comparison between the composite oxygen isotope and paleodepth curve for the Pleistocene-Holocene from 2.50 Ma to the Present. $10=2.45 \mathrm{Ma}$ LO of Globorotalia bononiensis; $11=1.75 \mathrm{Ma}$ LO Gephyrocapsa oceanica; $12=1.5 \mathrm{Ma}$ FO Gephyrocapsa spp. 13=1.25 LO Gephyrocapsa spp. $>5.5 \mu \mathrm{m} ; 14=0.99 \mathrm{Ma}=$ FO of Gephyrocapsa sp.3; 15 $=0.46 \mathrm{Ma}=\mathrm{LO}$ Pseudohemiliania lacunose; $16=0.26$ FO Emiliania huxleii. Ages of planktonic foraminiferal and calcareous nannofossils bioevents are astronomically tuned (Emeis et al., 1996; Di Stefano et al., 1996; Sprovieri et al. 1998).

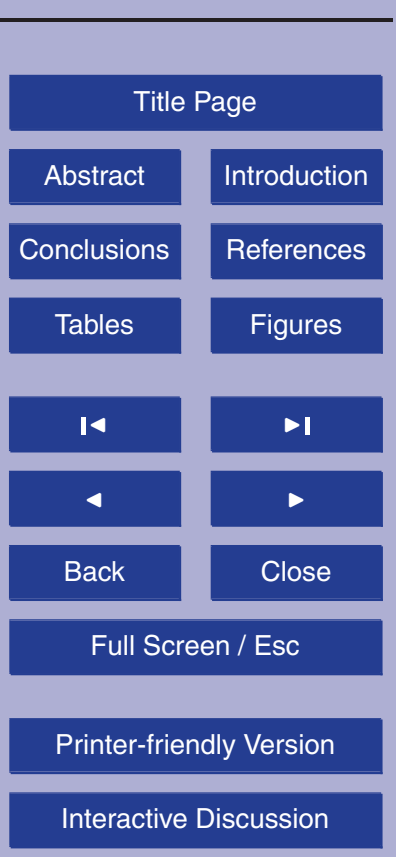

